\title{
EU vs Local Market Orientation: Western Balkan Entrepreneurs' Challenge
}

\author{
Gazmend Qorraj, Gezim Jusufi
}

\section{A B S T R A C T}

Objective: The main objective of the article is to analyse the relationship between entrepreneurs' profiles and their market orientation, i.e. to compare two groups of entrepreneurs - opportunity entrepreneurs and necessity entrepreneurs - to identify which group is international-export oriented.

Research Design \& Methods: Supported by questionnaires, the probit model is the method used to analyse 200 enterprises that operate in Kosovo as both export and non-export firms.

Findings: The main findings confirm that there is a relationship between the type of entrepreneur and market orientation; necessity entrepreneurs are less oriented towards international markets, while opportunity entrepreneurs are more focused on international markets.

Implications \& Recommendations: Among the main implications is one that shows entrepreneur type matters for market orientation. Therefore, the condition of trade liberalisation only is insufficient for the EU and international market orientation of entrepreneurs. In consideration of this fact, the main recommendation is to internally improve entrepreneurs' capability to exploit the EU and international markets in the future.

Contribution \& Value Added: The main contribution of this study is the demonstration of a link between the characteristics of entrepreneurs with entrepreneurs' market orientation; especially in the Western Balkans, a region characterised by long transitions, political tensions along with economic and institutional challenges. The added value of this research is the comparison of entrepreneurs on local markets with entrepreneurs on international markets based on their characteristics.

Article type: research article

Keywords: entrepreneurs; local market; necessity; opportunity; EU integration JEL codes: $\quad$ D21, F23, L26, P45

Received: 24 May 2019 Revised: 5 November 2019 Accepted: 10 November 2019

\section{Suggested citation:}

Qorraj, G., \& Jusufi, G. (2019). EU vs Local Market Orientation: Western Balkan Entrepreneurs' Challenge. Entrepreneurial Business and Economics Review, 7(4), 21-32. https://doi.org/10.15678/EBER.2019.070402 


\section{INTRODUCTION}

According to the World Bank Report (2008), we may attribute poor industrial performance in the Western Balkans to previous conflicts but also delayed transition, in some countries, poor economic management, and informal economy. The loss of markets in these countries seriously disrupted commercial and economic links among several neighbours and their main industrial partners, not to mention international production.

According to the Global Entrepreneurship Monitor report (GEM; 2018), most of Western Balkan countries are factor-driven economies. In such economies, research and development (R\&D) transfer, entrepreneurship education, government entrepreneurship programs, taxes, and bureaucracy are highlighted as areas that constrain entrepreneurship. Like other Western Balkan countries within the EU framework, Kosovo strives to enter the European Union and capitalize on the opportunities of the EU market. Therefore, in addition to the local market, it is crucial for local firms to penetrate the international markets, considering the opportunities of the EU market. There are many reasons why local entrepreneurs are less oriented towards international markets.

Different authors tackled the many theories regarding entrepreneurs' approach to the orientation towards the EU market. Pehrsson (2016) addresses the importance of international firms' in foreign markets; Dimitratos, Lioukas, and Carter (2004) discuss the uncertainty of domestic environment; Pissarides (2003) covers the limited technical expertise and growth issues; Acs and Audretsch (1993) scrutinize the role of small firms in Central Europe; while the informal sector and corruption are analysed by Shleifer and Vishney (1993). Wach, Głodowska, and Maciejewski (2018; 2019) analyse the impact of entrepreneurial orientation on the internationalisation of companies. Furthermore, Marcouiller and Young (1995), Scase and Goffee (1982) and Mclntyre (2003) analyse necessity-type entrepreneurs, who will be one of the subjects of this paper.

This research is crucial, as Western Balkan countries seek European integration. Hence, the correlation between the type of entrepreneur and their market orientation is key for the future of exporting trends of these countries. This research fills a knowledge gap by making a scientific contribution to the fields of entrepreneurship, market orientation, trade, and export. Apart from the type of entrepreneur and their capability to penetrate the international market, the additional contribution or value added of the research is the measuring of the level of experience, economic sectors, and the role of institutional support on export orientation. Supported by surveys, we employed the probit model along with descriptive statistics to analyse export and non-export enterprises. The main research questions are 1) whether opportunity entrepreneurs have a higher probability of participating in international markets, 2 ) whether the level of experience matters for export orientation, and, finally, 3) what is the role of institutional support and economic sectors on market orientation. The main objective of this study is to empirically analyse the relationship between the type of entrepreneur and their market orientation. The paper is structured as follows: following the introduction there is a review of the literature and the theory development. Then there is a discussion of the material and methods employed, followed by a presentation of the results. The main findings of the study are detailed and final conclusions are presented. 


\section{LITERATURE REVIEW}

The subject of market orientation is crucial for the development of entrepreneurship in the Western Balkans, considering that region has signed the regional free trade agreements known as CFETA 2006; not to mention that there are other market opportunities available from free trade with the European Union. While there are positive expectations for the Western Balkan countries with respect to free trade with the European Union, there is a low level of export on GDP creation - around 30\% - which is quite low compared to new EU member states. Furthermore, according to the World Bank Group (2017), the current economic growth in the EU creates opportunities for Western Balkan countries. Therefore, growth in the EU through exports affects growth among its trading partners, including the Western Balkans: a one \% point increase in GDP growth in EU-28 leads to an additional growth of $0.6 \%$ point of GDP in Albania and $0.27 \%$ points in Montenegro, with the impact falling in-between for FYR Macedonia, Serbia, Bosnia and Herzegovina, and Kosovo. Through regional ties, these countries also affect each other: a $1 \%$ point increase in GDP growth in Serbia motivates growth in Montenegro by $0.26 \%$ point. Regional integration is important for small countries because it facilitates entry into production chains the main vehicle of growth in productivity, exports, and output.

To that end, Zhang and Zhou (2016) measure the relationship between market orientation, innovation, and export performance of Chinese manufacturers only to confirm that the relationship is positive. Furthermore, in a study of Saudi Arabia, Alotaibi and Zhang (2017) conclude that export market orientation has a significant impact on export performance. Pascucci, Bartoloni, and Gregori (2016) analyse a sample of 300 Italian small and medium enterprises (SMEs) to find that the number of foreign markets and the presence of an export department is significantly and positively related to market orientation. According to Mac and Evangelista (2016), a significant component of export performance is a commitment to learning. Moreover, they found that market orientation may enhance export satisfaction while, conversely, negatively impacting firm profit.

Further evidence suggests that entrepreneurs in post-conflict countries often face economic, institutional, and legal obstacles, including limited access to working capital along with limited managerial and technical expertise (Pissarides et. al., 2003). Consequently, in many transition economies, especially in the Western Balkans, the small-firm sector has not grown rapidly enough to prevent the rise of unemployment, nor has it fulfilled its potential as an engine of growth (Acs \& Audretsch, 1993). Additional challenge for transition countries is the informal sector. In Kosovo, this phenomenon was mainly due to the predatory behaviour of government officials who expected bribes from anyone with officially registered economic activity (Shleifer \& Vishney, 1993). According to Marcouiller and Young (1995), bribery and corruption may result from inadequate institutional environment. Moreover, this informal environment provides incentives to devote resources to influencing regulators and encouraging unproductive entrepreneurship (Baumol, 1990). Such uncertainty may reduce productive investment and slow growth but also encourage the growth of bribery and corruption (Shleifer \& Vishney, 1993).

Furthermore, Wach, Głodowska, and Maciejewski $(2018$; 2019) confirm that entrepreneurial orientation can stimulate internationalisation much earlier than it is assumed in previous theoretical concepts, by combining entrepreneurial orientation, knowledge, 
and internationalisation. This research analyses necessity and opportunity entrepreneurs and their behaviour towards the EU market in order to measure their potential for international orientation and development; considering that an additional obstacle for local Kosovo entrepreneurs is their dominant necessity-type characteristic. In the 1990s, as Kosovo's employees lost their positions in public companies, they were forced to undertake their own economic activities to survive economically. In comparison to the rest of the region, an additional challenge for Kosovo firms is the restriction on the free movement of business people, insofar as Kosovo still faces barriers on migration to EU countries due to visa restriction. Consequently, the restricted movement has a negative impact on networking and partnership with EU firms, thereby increasing the transaction costs of local firms (Qorraj \& Jusufi, 2018).

The differences between necessity entrepreneurs and opportunity entrepreneurs were introduced in 2001 to clarify the distinction between entrepreneurship borne out of voluntary pursuit versus the need to engage in entrepreneurship due to the lack of employment opportunities. While necessity entrepreneurs are mainly present among the developing countries, where the lack of other alternatives pushes individuals to engage in entrepreneurial activities, opportunity entrepreneurs are individuals who are pulled into entrepreneurship activities due to their desire to apply their ideas or skills to entrepreneurial ventures. Scase and Goffee (1982) along McIntyre (2003) suggest that the majority of entrepreneurs in transition countries are necessity-based entrepreneurs rather than opportunity-based entrepreneurs. According to these authors, entrepreneurship is characterised by the reinvestment of business profits for the purpose of business growth and expansion.

The differentiation between the two above groups focuses on the motivation of entrepreneurs to initiate their own ventures (Reynolds, et al., 2005). Reynolds et al. explore the distinction between necessity entrepreneurs and opportunity entrepreneurs. Furthermore, Reynolds et al. find that necessity and opportunity entrepreneurs differ in their aspirations for growth. In GEM 2001, 14\% of opportunity entrepreneurs expected to create more than 20 jobs, whereas only $2 \%$ of necessity entrepreneurs had such expectations. A study by Block and Wagner (2006) in Germany finds that these two groups differ with respect to age, gender, region, and risk of becoming unemployed.

Opportunity entrepreneurs have been found to earn more, thereby having a stronger impact on economic growth. According to these results for Germany, it seems that necessity and opportunity entrepreneurship is not only significant for venture startups. Moreover, Bartlett, and Prasnikar (1995) confirm that most entrepreneurs in Slovenia have not been pushed into setting up a business by pressures of unemployment. The most important objective for most entrepreneurs was personal independence (57.6\%). In the case of Slovenia, entrepreneurs appear to be growth-oriented. According to the last report of the Global Entrepreneurship Monitor (GEM 2017-2018), most entrepreneurs around the world are opportunity-motivated. On average, three-quarters of respondents in the 2017 survey, just as in the 2016 survey, state that they chose to pursue opportunity as the basis of their entrepreneurial motivations.

In contrast, factor-driven economies report the lowest average opportunity motivation. Kosovo is identified as a factor-driven economy, based on the GEM Report (20172018) and confirmed by the study by Prasnikar, Koman, and Qorraj (2010). Analysed on a regional basis, North America has the most opportunity-driven entrepreneurs (around 
83\%), followed by Europe (75.4\%), Asia and Oceania (74.4\%), Latin America and the Caribbean (71.7\%), and Africa (70.9\%).

While other studies analyse the main factors that influence the export orientation of enterprises or barriers to trade, this research extends the analysis to consideration of the type of entrepreneur and market orientation in the Western Balkans. Moreover, this study answers the following questions. Does the type of entrepreneurs have an impact on export orientation? Does entrepreneurship experience matter for export capabilities? Does a branch or economic sector impact export performance? What is the role of institutional support on export orientation? Furthermore, this paper contributes to researchers, students, and policy-makers by providing a better understanding of the relationship between entrepreneurs and their potential to exploit international market opportunities, thus filling a knowledge gap in entrepreneurship and market-orientation, especially for the Western Balkans.

\section{MATERIAL AND METHODS}

This section presents the empirical results of the probit model analysis. We analysed around 200 firms in Kosovo by differentiating exporting firms or firms that currently operate in the international markets from non-exporting firms or firms that operate in the local markets. The aim of dividing the firms into two groups was to evaluate and compare the capacity and the challenges faced by entrepreneurs in local and international markets, but also to note the correlation between the type of entrepreneur and market orientation. The data and sample were collected by open surveys conducted at the end of 2018 and early 2019. We included two hundred local firms: 100 firms that currently operate in international markets and 100 firms that operate only in the local markets. We selected data for these firms from the National Customs Agency.

The survey was designed to provide representative data and avoid complexities, such as personal questions in order to address the main issues under consideration and obtain accurate data for the purpose of the study. The survey was conducted by an experienced researcher, followed by audio recordings and transcriptions. The researcher mainly interviewed owners and experienced managers of the enterprises. As Kosovo has a limited number of firms that operate in international markets, the sample of exporting firms is limited. By employing the following statistics, we will be able to understand the core challenges with regard to strategic orientations of Kosovo firms, both those in the international and the local market. We surveyed firms in the main regions of Kosovo.

Firms were randomly selected in order to perform the regional inclusiveness approach.

In this paper, we test the following hypotheses:

H1: Opportunity-based entrepreneurs are more likely to access the EU market.

H2: The level of experience increases the export capabilities of entrepreneurs.

H3: The economic sector, i.e. industry branch, affects export orientation.

H4: Firms that possess more institutional support (funds or technical support from the government) are more likely to access the EU market.

The econometric model used in this study is as follows:

$$
P\left(Y_{i}=1\right)=\Phi\left(\beta_{0}+\beta_{1} x_{i 1}+\beta_{2} x_{i 2}+\beta_{3} x_{i 3}+\beta_{4} x_{i 4}+\varepsilon\right)
$$


in which $\mathrm{y}=$ export orientation; $\beta_{0}=$ regression coefficient; $\mathrm{X} 1$ = characteristics of entrepreneurs (whether they are necessity or opportunity entrepreneurs); X2 = business experience (years in business; does the current exporter work with international firms in local markets?); X3 = economic sectors (in which sectors are concentrated into exporting vs local firms); $X 4$ = institutional support (funds and technical support from the local government); and $\varphi=$ error term. The model explores the relationship between the type of entrepreneur and market orientation. The main variables will be the type of entrepreneur, business experience, sector concentration, and the financial and technical support from the local government.

\section{Variables Descriptions and Measurement}

The levels of variables in the table below appear nominal. Only business experience is scale variable. Scale variable is a measurement variable and has a numeric value. The nominal variable is the most basic level of measurement. The nominal level measurement uses symbols to classify observations into mutually exclusive and exhaustive categories. Mutually exclusive means that categories must be distinct so that no observation falls into more than one category. Exhaustive means that there must exist sufficient categories so that each observation falls into at least one category. Over the years, only business experience variable has been expressed as ordinal or scale.

Table 1. Variables description

\begin{tabular}{|l|l|}
\hline \multicolumn{1}{|c|}{ Dependent variable } & \multicolumn{1}{c|}{ Variables descriptions and measurement } \\
\hline \multicolumn{1}{|c|}{ Indepent orientation } & 1-EU Market Orientation, 0 - Local Market Orientation \\
\hline $\begin{array}{l}\text { Characteristics of entrepre- } \\
\text { neurs }\end{array}$ & \multicolumn{1}{|c|}{ Variables descriptions and measurement } \\
\hline Business experience & Years since starting with exports \\
\hline Economic sectors & $\begin{array}{l}\text { The most widespread manufacturing sectors in Kosovo: } \\
\text { Production of plastic doors and windows (Reference category), } \\
\text { 1-Furniture, 2-Food industry, 3-Beverage industry, } \\
\text { 4-Processing of metals }\end{array}$ \\
\hline Institutional support & 1-Institutional support from local government, 0-otherwise \\
\hline
\end{tabular}

Source: own study.

The choice of proper statistical technique very much depends on the dependent variable under testing. Probit and logit models are types of generalised linear models. Both can be used for modelling the relationship between one or more numerical or categorical predictor variables and a categorical outcome. In both logit and probit models, a binary outcome must be coded as 1 or 0 . In our model, the dependent variable Export Orientation is coded as 1 - EU Market Orientation and 0 - Local Market Orientation. The real difference is theoretical. They use different link functions. Logistic regression uses a logit link function, while a probit regression uses an inverse normal link function. Economists like the probit model because it can be given a latent normal interpretation; the distribution of the response is relayed onto a continuous normal variable. In conclusion, choosing the right model depends on the individual preferences of researchers. 


\section{RESULTS AND DISCUSSION}

The following is an explanation and discussion of the performed analysis. Table 2 represents the total number of firms that export to the EU and other international markets.

Table 2. The total number of Kosovo enterprises that export to the EU and other countries

\begin{tabular}{|c|c|c|c|}
\hline \multirow{2}{*}{ Years } & \multirow{2}{*}{$\begin{array}{c}\text { Total number } \\
\text { of enterprises }\end{array}$} & $\begin{array}{c}\text { The number of enterprises } \\
\text { that export to the EU }\end{array}$ & $\begin{array}{c}\text { The number of enterprises that } \\
\text { export to other countries }\end{array}$ \\
\cline { 3 - 4 } & & 244 & 386 \\
\hline 2014 & 9404 & 229 & 421 \\
\hline 2015 & 9833 & 210 & 456 \\
\hline 2016 & 10424 & 257 & 443 \\
\hline 2017 & 9223 & \multicolumn{2}{|c}{ Type of firms } \\
\hline
\end{tabular}

Source: Kosovo Agency of Statistics (2018).

The entrepreneurs who operate with the EU and other international markets represent approximately $63 \%$ and are opportunity entrepreneurs. In contrast, entrepreneurs who operate on the local market seem to be relatively frequent, around $83 \%$. This is an indication that firms which operate in the international markets have a growth-oriented approach and, therefore, increase their competitive capabilities as a strategy. Conversely, local firms mostly have a local approach; their lack of information and technical expertise prevents them from benefitting from opportunities that come from foreign markets. Moreover, we compared the receipt of technical or financial support from local institutions and international donors by firms that operate on the international market and those that do not operate on the international market. Only $9 \%$ of the firms that operate on the international market received funds and technical support from local institutions and donors, while only $4 \%$ of firms that operate on local markets absorbed funds and technical support from local institutions. This financial support improves the corporate governance of the firms. Furthermore, about $53 \%$ of enterprises that export to the EU market were established after 1989 and in 2000-2010, while around $80 \%$ of enterprises that operate in local markets were established after 2010. Most of the enterprises that export to the EU market (around 21\%) are involved in production-related activities such as plastic doors and windows, while enterprises that operate in local markets are mostly involved in the furniture sector (around $23 \%$ ).

In our model, the pseudo $R 2$ is 0.29 . Changes in independent variables also because the change in the value of this test. LR chi2 is the likelihood ratio (LR) chi-square test. The value of this test is 31.02 . The Prob>chi2 shows that the coefficients jointly are highly significant. The value of this test is 0.03 . Moreover, the Wald test - a test for exclusion restrictions - is 27.04 .

In Table 3, we present results estimated from the binary probit model or probit coefficients for both groups of entrepreneurs. The variables include the characteristics of an entrepreneur's business experience, economic sector, and institutional support. Below, please find an explanation of the variables estimated in the model, used to analyse their impact on entrepreneurs' export orientation (supported by the results of Table 3). 
Table 3. Enterprises that export to the EU markets vs enterprises on local marketsProbit Model Estimation Results

\begin{tabular}{|c|c|c|c|c|c|c|c|c|c|}
\hline \multirow[t]{2}{*}{ Parameter } & \multirow[t]{2}{*}{ B } & \multirow[t]{2}{*}{ Std. Error } & \multicolumn{2}{|c|}{ 95\% Wald Confidence Interval } & \multirow[t]{2}{*}{ df } & \multirow[t]{2}{*}{ Sig. } & \multirow[t]{2}{*}{$\operatorname{Exp}(B)$} & \multicolumn{2}{|c|}{$\begin{array}{l}\text { 95\% Wald Confidence } \\
\text { Interval for } \operatorname{Exp(B)}\end{array}$} \\
\hline & & & Lower & Upper & & & & Lower & Upper \\
\hline Characteristics of entrepreneurs & 1.035 & 0.209 & 0.624 & 1.447 & 1 & $0.000 * *$ & 2.816 & 1.867 & 4.249 \\
\hline Business experience & 0.32 & 0.010 & -0.053 & -0.012 & 1 & $0.002 * *$ & 1.009 & 0.952 & 1.990 \\
\hline
\end{tabular}

Production of plastic door and window (Reference category)

\begin{tabular}{|c|c|c|c|c|c|c|c|c|c|}
\hline Furniture (1) & 0.892 & 0.412 & -0.398 & 1.240 & 1 & $0.030 * *$ & 2.440 & 0.845 & 2.586 \\
\hline Food industry (2) & 0.752 & 0.516 & 0.153 & 1.761 & 1 & 0.145 & 2.122 & 0.677 & 2.209 \\
\hline Beverage industry (3) & 0.199 & 0.484 & -0.014 & 1.772 & 1 & 0.681 & 1.221 & 0.621 & 1.328 \\
\hline Processing of metals (4) & -0.826 & 0.754 & -0.323 & 1.395 & 1 & 0.273 & 0.438 & 0.327 & 0.491 \\
\hline Institutional support & 0.155 & 0.390 & -0.053 & 1.230 & 1 & 0.234 & 1.167 & 0.948 & 1.436 \\
\hline Constant & -3.203 & 1.421 & - & - & 1 & 0.024 & 0.041 & - & - \\
\hline
\end{tabular}

Notes: ${ }^{* *}$ significant at $5 \%$.

Source: own calculations. 
A characteristic of entrepreneurs shows a positive relationship appears between the type of entrepreneur and their market orientation; around $63 \%$ of the enterprises that export to the EU and other markets are opportunity entrepreneurs. In contrast, $83 \%$ of enterprises that operate on the local market are necessity entrepreneurs. The positive coefficient means that an increase in the independent variable leads to an increase in the predicted probability. Moreover, based on the probit model, the odds ratio is 2.816 , which indicates that - due to their characteristics - entrepreneurs who operate on the EU markets have a higher probability of exporting to an EU market in comparison to the second group.

Business Experience confirms the positive correlation between experience and exporting trends, demonstrating that experience matters for export orientation. Our analysis shows that 53\% (resp. 41\%) of export-oriented enterprises were established in the period 2000-2010, while about 12\% were established even earlier, after 1989. In contrary, most of the firms (around $80 \%$ ) that operate in local markets are established after 2010, while around $20 \%$ before 2010. The odds ratio of Business Experience is 1.009 , which means that longer business experience increases the chances to export, so firms that operate in EU markets - due to their long-term experience - are in a better position in comparison to firms oriented locally.

Economic sectors highlights as the first reference category the production of plastic doors and windows. This dummy will not be included in the analysis. As visible from the figures of the other four categories, only the firms involved in the category of processing metals $(0.438)$ has no positive relationship with the reference category. The firms that deal process metals have a lower probability of orientation towards the EU market than firms that produce plastic doors and windows. Firms of the other three categories have a positive relationship with the reference category. Therefore, these firms (involved in such sectors as the furniture sector, the food sector, or the beverage sector) and the firms from the reference category sector (plastic doors and windows) are likely to orient themselves towards the EU market.

With regard to Institutional Support, there is evidence that only around $9 \%$ of the exporting firms were supported by local institutions, while $4 \%$ of firms that are concentrated in local markets receive institutional support. According to the results, while institutional support from the local government is insufficient, we may confirm that export-oriented enterprises benefit from institutions in comparison to local-oriented enterprises. Although the variable is not significant, the coefficient shows that the higher the institutional support, the greater the opportunities for enterprises to export to the EU market.

Compared to other studies and authors such as Wach, Maciejewski, and Głodowska (2018), who connected entrepreneur orientation with internationalisation, and McIntyre (2003), who studied the type of the entrepreneur, this paper combines the type of entrepreneur with market orientation and internationalisation, respectively the impact of the type of entrepreneur on market orientation.

\section{CONCLUSIONS}

The current business environment in the Western Balkans still constrains local entrepreneurs from penetrating the EU market. Despite a few improvements in the business environment, local entrepreneurs in Western Balkan countries, especially Kosovo, still face many external obstacles. 
While necessity entrepreneurs are mainly characteristic of developing countries, in which the lack of other alternatives pushes individuals to engage in entrepreneurial activities, there is evidence that most of Kosovo's entrepreneurs are necessity- rather than opportunity-driven entrepreneurs. According to our survey, around $63 \%$ of entrepreneurs oriented towards the EU market are opportunity entrepreneurs, while $83 \%$ of the entrepreneurs oriented towards the local market are necessity driven. Therefore, our results reveal that, despite the benefits provided by various regional and EU trade agreements, firms from Kosovo cannot be sufficiently developed to compete in the international and EU markets due to their entrepreneur type, mostly locally-driven.

Although local enterprises in Kosovo do not have a long tradition in business activities in comparison to other countries, business experience has a positive impact on their sustainability and export orientation.

Besides, due to financial limitations, support from the local government and other stakeholders is small, while technical and financial support increases the probability of enterprises access the EU and the international market.

With regard to economic sectors, informed entrepreneurs with a long-term vision usually adapted their activities and production in accordance with EU standards, showing that the EU and global market changes affect their investments and market behaviours.

Moreover, the probit model offers explanations for our hypotheses:

- due to the capabilities of opportunity entrepreneurs, they have more chances to access the EU and achieve international market orientation,

- experience with the business environment matters for export orientation,

- economic sectors, i.e. industry branches, are an important but not sufficient condition for export orientation,

- local institutional support increases the probability that enterprises are export-oriented in comparison.

Finally, to target EU market needs, the local government should implement long-term policies - including technical and financial support - and provide valuable information about new industry trends, technologies, and market needs within the EU.

This paper demonstrates the interlinkage of entrepreneur types with market orientation; therefore, the type of entrepreneur matters for export orientation in the Western Balkans, especially Kosovo. Further added value of this research is the comparison of entrepreneurs who operate in local markets with entrepreneurs on the international market. The main limitation of this paper is the limited number of enterprises oriented at the international market, given the small sample of enterprises available for analysis in Kosovo. Finally, an additional issue is the short observation period. It is possible to extend our research by monitoring export trends in the future and analysing whether the number of exporting enterprises will increase due to improvements in the general business environment in Kosovo or due to the advancement of quality in production, market experience, and networks that involve international enterprises.

\section{REFERENCES}

Acs, Z., \& Audretsch, D. (1993). Small Firms and Entrepreneurship: An East-West Perspective. Cambridge: Cambridge University Press. 
Alotaibi, M.B.G., \& Zhang, Y. (2017). The relationship between export market orientation and export performance: An empirical study. Applied Economics, 49(23), 2253-2258. https://doi.org/10.1080/00036846.2016.1237743

Baumol, W.J. (1990). Entrepreneurship: Productive, unproductive and destructive. Journal of Political Economy, 98(5), 893-921.

Bartlett,V., \& Prasnikar, J. (1995). Small firms and economic transformation in Slovenia. Communist Economies and Economic Transformation, 7(1), 83-103.

Block, J.H., \& Wagner, M. (2006). Necessity and Opportunity Entrepreneurs in Germany; Characteristics and Earnings Differentials. SSRN.

Dimitratos, P., Lioukas, S., \& Carter, S. (2004). The relationship between entrepreneurship and international performance: The importance of domestic environment. International Business Review, 13(1), 19-41.

GEM (2018). Global Entrepreneurship Monitor 2018; Global Report. 2018. Global Entrepreneurship Research Association (GERA).

Głodowska, A., Maciejewski, M., \& Wach, K. (2019). How Entrepreneurial Orientation Stimulates Different Types of Knowledge in the Internationalisation Process of Firms from Poland?. Entrepreneurial Business and Economics Review, 7(1), 61-73. https://doi.org/10.15678/EBER.2019.070104

Kosovo Agency of Statistics (2018), Statistical Report of Enterprises in Kosovo, 2014-2017; Total number of Kosovo firms, exporting firms to the $\mathrm{EU}$ and in other countries.

Mac, L., \& Evangelista, F. (2016). The relative impact of market orientation and entrepreneurship on export performance: Do we really know enough? Journal of Global Marketing, 29(5), 266-281. https://doi.org/10.1080/08911762.2016.1196285

Marcouiller, D., \& Young, L. (1995). The black hole of graft: The predatory state and the informal economy. American Economic Review, 85, 630-646.

McIntyre, R. (2003). Small Enterprises in Transition Economies. Hampshire, UK: Palgrave.

Pascucci, F., Bartoloni, S., \& Gregori, G.L. (2016). Export market orientation and international performance in the context of SMEs. Journal of Small Business \& Entrepreneurship, 28(5), 361-375. https://doi: 10.1080/08276331.2016.1167528

Pehrsson, A. (2016). Firm's strategic orientation, market context, and performance, European Business Review, 28(4), 378-404.

Pissarides, F., Singer, M., \& Svejnar, J. (2003). Objectives and constraints of entrepreneurs: evidence from small and medium size enterprises in Russia and Bulgaria. Journal of Comparative Economics, 31(5), 503-531.

Prasnikar, J., Koman, M., \& Qorraj, G. (2010).The Entrepreneurship in developing countries. A Case of Kosovo. Journal of Transformation in Business and Economics, 9(3).

Qorraj, G., \& Jusufi, G. (2018). The EU stabilization and association agreement for the Western Balkans: Challenges and opportunities. (CIRR) Croatian International Relations Review, 24(81).

Reynolds, P.D., Bosma, N., Autio, E., Hunt, S., de Bono, N., Servais, I., Lopez-Garcia, P., \& Chin, N. (2005). Global entrepreneurship monitor: Data collection design and implementation 19982003. Small Business Economics, 24(3), 205-231.

Scase, R., \& Goffee, R. (1982). The Entrepreneurial Middle Class. London: Croom Helm.

Shleifer, A., \& Vishney, R. (1993). Corruption. Quarterly Journal of Economics, 108(3), 599-617.

Wach, K., Głodowska, A., \& Maciejewski, M. (2018). Entrepreneurial orientation, knowledge utilization and internationalization of firms. Sustainability, 10(12), 1-23. https://doi.org/10.3390/su10124711

World Bank, (2008). Business Condition Index in Kosovo: Doing Business in Kosovo. 
World Bank Group. 2017. Western Balkans Regular Economic Report No. 12, Fall 2017: Job Creation Picks Up. World Bank, Washington, DC. Retrieved from https://openknowledge. worldbank.org/handle/10986/28883 License: CC BY 3.0 IGO on May 5, 2019.

Zhang J., \& Zhou, M. (2016). Market orientation, product innovation and export performance: Evidence from Chinese manufacturer's. Journal of Strategic Marketing, 24, 377-397.

\section{Authors}

The contribution of co-authors is equal and can be expressed as $50 \%$ each of the authors:

G. Qorraj prepared the literature review while G. Jusufi prepared the statistical calculations.

\section{Gazmend Qorraj}

Associate Professor at the Faculty of Economics, the University of Prishtina. He received his PhD from the University of Ljubljana in 2009 and MA in the economics of international trade and European integration in 2004 from Staffordshire University, UK, and Vrije University, Brussels. Since 2001, Qorraj has taught at the University of Prishtina. Since 2015, he is the NCP for the Marie Curie Actions \& European Research Council at HORIZON 2020.

Correspondence to: Prof. Gazmend Qorraj, PhD, University of Pristina, Faculty of Economics, 10000, Str. Agim Ramadani, n.n. Prishtina, 10000, e-mail: gazmend.qorraj@uni-pr.edu

ORCID (1) http://orcid.org/0000-0002-9012-8918

\section{Gezim Jusufi}

$\mathrm{PhD}$ candidate in economics at the University of Prishtina. He received an MA in marketing in 2011 from the University of Prishtina and a diploma in business administration in 2009 from Trakya University, Turkey.

Correspondence to: Gezim Jusufi, University of Pristina, Faculty of Economics, Str. Agim Ramadani, n.n. Prishtina, 10000, e-mail: gezimi.gjilan@gmail.com

ORCID (1) http://orcid.org/0000-0003-4338-3331

\section{Copyright and License}

This article is published under the terms of the Creative Commons

Attribution - NoDerivs (CC BY-ND 4.0) License

http://creativecommons.org/licenses/by-nd/4.0/

Published by the Centre for Strategic and International Entrepreneurship - Krakow, Poland 